\title{
Growth and the Lost Legitimacy of Business Organisation: Time to Abandon Corporate Law Reform
}

DOI:

10.1080/14735970.2019.1679418

\section{Document Version}

Accepted author manuscript

Link to publication record in Manchester Research Explorer

\section{Citation for published version (APA):}

Galanis, M. (2019). Growth and the Lost Legitimacy of Business Organisation: Time to Abandon Corporate Law Reform. Journal of Corporate Law Studies, 20(2), 291-325. https://doi.org/10.1080/14735970.2019.1679418

\section{Published in:}

Journal of Corporate Law Studies

\section{Citing this paper}

Please note that where the full-text provided on Manchester Research Explorer is the Author Accepted Manuscript or Proof version this may differ from the final Published version. If citing, it is advised that you check and use the publisher's definitive version.

\section{General rights}

Copyright and moral rights for the publications made accessible in the Research Explorer are retained by the authors and/or other copyright owners and it is a condition of accessing publications that users recognise and abide by the legal requirements associated with these rights.

\section{Takedown policy}

If you believe that this document breaches copyright please refer to the University of Manchester's Takedown Procedures [http://man.ac.uk/04Y6Bo] or contact uml.scholarlycommunications@manchester.ac.uk providing relevant details, so we can investigate your claim.

\section{OPEN ACCESS}




\title{
Growth and the Lost Legitimacy of Business Organisation: Time to Abandon Corporate Law ${ }^{1}$ Reform
}

\author{
Michael Galanis*
}

\begin{abstract}
Business organisation still reflects and reproduces the dated idea of 'economic growth as progress' irrespective of its social hazards. Recalibrating the grounding of business organisation's legitimacy requires radical legal reform in order to accommodate the relegation of growth as a lower order objective. However, this article shows that the normative debate in corporate law scholarship is unable to resolve the legitimacy problem of business organisation and ultimately reflects and reproduces the ideal of 'growth as progress'. The problem is corporate law per se. Thus, the article argues that, even if these normative difficulties could be surpassed, instituting a new legitimacy for business organisation through corporate law reform - the conventional remedy - is, at best, practically impossible or, worse, harmful, because it is bound to follow conformist logic. Consequently, it is preferable to abandon corporate law reform completely and policy should focus instead on enabling the radical organisational practice already occurring in the social margin.
\end{abstract}

Keywords: Corporate law, business organisation, economic growth, bureaucracy, managerial capitalism.

\section{Introduction}

There is little doubt about the prominence of economic accumulation, measured by GDP growth, as a public policy objective and measure of progress. ${ }^{2}$ However, if indeed economic accumulation has facilitated social progress - e.g. in the form of improved health and life expectancy (for some), comfort or technology (for some) - it now seems that pursuing it further is clearly a rather dangerous choice which can lead to social decline. On the one hand, the correlation between economic growth and happiness is no longer evident. ${ }^{3}$ On the other, the

\footnotetext{
* Senior lecturer in company law, University of Manchester School of Law. The author is indebted to Vincenzo Bavoso, Alan Dignam, David Kershaw, Marc Moore, Jasem Tarawneh and the anonymous reviewers for their thorough comments on earlier versions of this work. A special thanks for their feedback is also owed to the participants at the Harvard Law School - IGLP conference 'Law in Global Political Economy: Heterodoxy Now' held on 2-3 June 2018, and at the University of Cambridge, 3CL Research Seminar Series, where this work was presented. All errors and omissions are of the author.

1 "Corporate law" in this article refers to the basic anatomy of the law governing corporations in a similar manner to that suggested in Armour, J. , Hansmann, H. and Kraakman, R., "What Is Corporate Law?" in Armour, J. et al., The Anatomy of Corporate Law: A Comparative and Functional Approach, 2nd ed. (Oxford University Press, 2009), 1-34.

${ }^{2}$ Masood, E., The Great Invention: The Story of GDP and the Making (and Unmaking) of the Modern World (Pegasus Books, 2016); Victor, P., Managing without Growth (Elgar, 2008), at 4-14.

${ }^{3}$ Easterlin, R., "Does Economic Growth Improve the Human Lot? Some Empirical Evidence" in David, P. and Reder, W., Nations and Households in Economic Growth (Academic Press, 1974), 89; Easterlin, R., "Paradox Lost?" (2017) 4(4) Review of Behavioral Economics 311. For a critique see Stevenson, B. and Wolfers, J.,
} 
scientific community has already confirmed the environmental footprint of economic growth per se leads to numerous public health, food scarcity and social risks of existential scale for large parts of the human population. ${ }^{4}$ A fairly bleak picture of our immediate future emerges which questions the legitimacy of current social, and therefore business, choices and necessitates a radical change of course. Thus, an expanding literature has already emerged calling for the redirection of society to distance itself from the economic growth ideal as a prime objective in order to avert the latter's social hazards. ${ }^{5}$ However, such paradigm change cannot ensue, unless it is embedded in our institutional structure. In recent years, the discussion on the organisational changes required for such social redirection has been intensifying, spanning from general social institutional structures to more business-specific ones. ${ }^{6}$

This article seeks to contribute to this literature by firstly showing that such social change will unavoidably have to include radical business organisation law reform. The primary focus is on corporate law, the predominant organisational form for business, and its capacity to accommodate a legitimacy ground which is not primarily focused on economic growth. The social importance of this stems from the current role of corporate law as an institution reflecting and reproducing the quintessential for capitalism idea of "growth as progress" which, as a result, becomes a structural problem; corporate law is antagonistic to society's need to meet its current challenges within capitalism. Thus, the main endeavor here is ultimately to explore whether this structural problem, which directly reflects upon the legitimacy of business organisation, can be resolved or at least mitigated directly by corporate law reform, the

\footnotetext{
"Economic Growth and Subjective Well-Being: Reassessing the Easterlin Paradox", NBER Working Paper No. $14282,2008$.

${ }^{4}$ E.g. Georgescu-Roegen, The Entropy Law and the Economic Process (Harvard University Press, 1971); more recently, Jackson, T., Prosperity without Growth: Economics for a Finite Planet (Routledge, 2009) and Victor, supra. n2. Also Fernández-Amador, O. et al., "Carbon Dioxide Emissions and Economic Growth: An Assessment Based on Production and Consumption Emission Inventories" (2017) 135 Ecological Economics 269 and Raftery, A. et al., "Less than $2^{\circ} \mathrm{C}$ Warming by 2100 Unlikely" (2017) 7 Nature Climate Change 637 confirming growth off-sets any positive impact of $\mathrm{CO}_{2}$ emission reduction efforts.

${ }^{5}$ E.g. Latouche, S., Farewell to Growth (Polity Press, 2010); Higgs, K., Collision Course: Endless Growth on a Finite Planet (MIT Press, 2014); Rist, G., The Delusions of Economics: The Misguided Certainties of a Hazardous Science (Zed Books, 2011); Jackson, T., Prosperity without Growth; Foundations for the Economy of Tomorrow, 2nd edn. (Routledge, 2016); Georgescu-Roegen, supra. n4 and Victor (2008), supra. n2.

${ }^{6}$ Indicatively see Johnsen, C. et al. (eds), Organizing for the Post-Growth Economy (2017) 17(1) Ephemera: Theory and Politics in Organization, Special Issue; Cumbers, A. and McMaster, R. "Revisiting Public Ownership: Knowledge, Democracy and Participation in Economic Decision Making (2012) 44(3) Review of Radical Political Economics 358. Some notable exceptions discussing business organisations are Rothschild-Whitt, J., "Workers' Cooperatives and Social Enterprise: A Forgotten Route to Social Equity and Democracy" (2009) 52(7) American Behavioral Scientist 1023; Ranis, P., Cooperatives Confront Capitalism: Changing the Neoliberal Economy (Zed Books, 2016); Parker, M., "Alternative Enterprises, Local Economies, and Social Justice: Why Smaller is Still More Beautiful" (2017) 20(4) Management 418.
} 
conventional technique. To put it more simply the question is whether corporate law reform can instigate social change.

While corporate scholarship, broadly defined, has for many years debated the social role and legitimacy of business organisation and of corporate law in particular, it will be shown that no alternative to "growth as progress" emerges from the way this debate has been framed. This because it either bases the legitimacy of corporate law directly or indirectly on its growth orientation per se or it fails to recognise the structural significance of the corporation as a business organisation form that reproduces the growth paradigm. Consequently, corporate scholarship has been unable to offer a convincing way of turning corporate law into a social change instrument which could restore the legitimacy of business organisation. To do so and, thus, to assist in resolving the structural problem mentioned above, the normative debate would need to adopt a more radical approach towards corporate law reform.

However, what seems like a failure of corporate scholarship is no coincidence and can be fully explained. It will be shown here that a radical reframing of corporate law necessitates the modification of the corporation's essential features to such an extent that it renders legal reform practically impossible. This explains why any realistic change to corporate law remains patchy and ineffective or tends to follow conventional logic that causes more harm than good. Given corporate law's dominance, this finding is of immense importance for policy-making, because it reveals that if we wish to radically redesign the purpose of business organisation law outside the economic growth paradigm, we have to abandon corporate law reform altogether. In short, corporate law cannot promote social change because corporate law is the problem. This is not merely a negative finding. Having established that business organisation law reform is necessary, this realisation positively indicates that, contrary to what is conventionally believed, policy effort should shift its focus away from corporate law and towards facilitating radical organisational practice which is already taking place in the social margin. This will enhance both the effectiveness and the social legitimacy of such policy as well as of business organisation.

The discussion will proceed as follows. The next part will explore how the idea of "growth as social progress" became a central principle of social organisation, which gradually led to business organisation law becoming predominantly corporate law ("corporatisation"). The third part will then show how corporate law has then impacted on society by becoming a central institution for the reproduction of the growth-oriented paradigm at all costs; this is the root of the legitimacy problem faced by business organisation. The fourth part will then revisit the main normative strands of corporate scholarship seeking a legitimacy basis for the corporatised 
business organisation, and show how it has failed to identify and tackle the root of the problem, namely that corporate law is a growth-oriented institution. The fifth part will then demonstrate that attempting to resolve the legitimacy problem with corporate law reform is, in fact, futile or bound to exacerbate it. In this light, the final part will conclude and propose an alternative strategy for scholarship research and policy-making, which can have a higher potential for reestablishing the social legitimacy of business organisation (law).

\section{2. "Growth as Progress" and the "Corporatisation" of Business Organisation Law}

Even a superficial look at the current organisational landscape of private business demonstrates that the principal legal vehicle adopted today is the corporation and to a lesser extent other quasi-corporate structures. ${ }^{7}$ This "corporatisation" of business organisation law may not surprise the reader today, but it is by no means a natural organisational development. Rather, it is a social choice which can be traced in the deeper cultural origins of capitalism itself, namely the specific idea of "growth as progress". Exploring the association between this idea - or more simply capitalism - and the dominance of corporate law as a structure for business is necessary for appreciating the social legitimacy problem and potential role of the law in this field. In fact, this relation is actually based on a bi-directional causality: while the advent of capitalism instigated legal transformation concerning business organisation, eventually the law in this area has evolved into a structural force behind the drive for economic growth, the principal characteristic of capitalism. The discussion in this part concentrates on the first type of this dynamic relationship (the reverse type will be discussed in part 3 below), that is on how capitalism as radical social change necessitated the use of corporate law for structuring business due to its strong predisposition towards growth.

The radical nature of capitalism is perhaps more strikingly evidenced by the fact that accelerated economic growth is a unique occurrence in human history, which began in Europe from the late $18^{\text {th }}$ century onwards before it became a global trend; until then economic growth was stable at fairly low levels. ${ }^{8}$ The explanation for this rests within the sociohistorical circumstances of European society around that time. As Mokyr ${ }^{9}$ recently reminded us, the

\footnotetext{
${ }^{7}$ Indicatively, out of 1.4 million businesses with employees in the UK, 1 million were organised as companies or limited liability partnerships; see Department for Business, Energy \& Industrial Strategy, Business Population Estimate for the UK and Regions 2018, https://www.gov.uk/government/statistics/business-population-estimates2018 (accessed on 25 June 2019).

${ }^{8}$ Maddison, A., The World Economy: A Millennial Perspective (OECD, 2001).

${ }^{9}$ Mokyr, J., A Culture of Growth: The Origins of the Modern Economy (Princeton University Press, 2017).
} 
phenomenon of economic growth is only a surface reflection of a culture which proliferated and transformed western societies. This social transformation is associated with the idea of attaining material progress through applied scientific knowledge and human reason, a belief forcefully propagated by figures like Bacon, Comte, Descartes and others. ${ }^{10}$ This account mirrors Weber's influential claim that capitalism is rooted in the "disenchantment" of society, ${ }^{11}$ i.e. the gradual retreat of religious frames for rationalizing the world, human action and existence, which followed the scientific developments since the Renaissance and the Enlightenment. ${ }^{12}$

The secularisation of western culture created social space for a radical transformation of cultural values which became less focused on metaphysical salvation and more on the practicalities of the material world that could be resolved by human reason and knowledge. This drive for "betterment" through scientific and material progress was ultimately externalised through consumption and material accumulation not as a means for subsistence but as a social end. ${ }^{13}$ That was a fundamentally new way of conceiving individual and social identity as well as purposes, which paved the way for a particular type of economistic utilitarianism - the kind Enzioni ${ }^{14}$ criticised as one-dimensional and individualistic - to proliferate and give social legitimacy to the pursuit of private material accumulation. ${ }^{15}$ In short, contrary to what Adam Smith ${ }^{16}$ advocated, endless economic accumulation, the "spirit of capitalism", ${ }^{17}$ is not a "propensity in human nature" but rather it echoes a gradual collective re-imagining of social values and purposes. As forcefully demonstrated by Ostrom, ${ }^{18}$ the homo oeconomicus, the rational wealth maximiser of the economic worldview, is a social creation rather than a natural type of being; Bouchard has called it a social myth. ${ }^{19}$ Even so, it has been a very dominant

\footnotetext{
${ }^{10}$ Bury, J., The Idea of Progress: an Inquiry into Its Origin and Growth (Macmillan, 1920).

${ }^{11}$ Weber, M., "Science as a Vocation" (1918) in Gerth, H. and Wright-Mills, C. (transl. and eds.), From Max Weber: Essays in Sociology (Oxford University Press, 1946), 129.

${ }^{12}$ On the retreat of religious rationalities in Europe see Somerville, J., The Secularization of Early Modern England: From Religious Culture to Religious Faith (Oxford University Press, 1992); Nadon, C. (ed.), Enlightenment and Secularism: Essays on the Mobilization of Reason (Lexington, 2013); Harrison, P., "Science and secularization" (2017) 27(1) Intellectual History Review 47.

${ }^{13}$ Campbell, C., The Romantic Ethic and the Spirit of Modern Consumerism (Blackwell, 1987).

${ }^{14}$ Etzioni, A., The Moral Dimension: Toward a New Economics (Free Press, 1988).

${ }^{15}$ Marc Raeff has called this "possessive individualism"; Raeff, M., "The Well-Ordered Police State and the Development of Modernity in Seventeenth- and Eighteenth-Century Europe: An Attempt at a Comparative Approach (1975) 80(5) American Historical Review 1221, 1239.

${ }^{16}$ Smith, A., An Inquiry into the Nature and Causes of the Wealth of Nations (orig. 1776), Campbell, R. and Skinner, A. (eds), (Clarendon Press, 1976), 25.

${ }^{17}$ Weber, M, The Protestant Ethic and the Spirit of Capitalism (1905), transl. Parsons, T. (Routledge, 2005).

${ }^{18}$ Ostrom, E., "A Behavioral Approach to the Rational Choice Theory of Collective Action" (1998) 92(1) American Political Science Review 1.

${ }^{19}$ Bouchard, G., Social Myths and Collective Imaginaries (University of Toronto Press, 2017), 30.
} 
phantasy that still defines individual action and public policy ${ }^{20}$ so long as economic growth is retained as a primary objective.

In fact, the recognition that the human faculty of imagination is a driver behind social structuring and transformation has been gaining prominence for some time now. ${ }^{21}$ In this regard, very influential has been Castoriadis" original conception of the "social imaginary" as the collective imagination which defines and supports a society's primary rationalisation frame and thus serves as a central guiding principle of social action and organisation. ${ }^{22}$ On this basis, Castoriadis delves deep in the human psyche (within capitalist society) to discover that materialist accumulation as a social end is the manifestation of an irrational human phantasy of omnipotence. This phantasy appears in the guise of a "(pseudo)rational (pseudo)mastery" over nature founded on the belief in human reason's capacity to fill the vacuum left by the retreat of finite life's religious rationalisations. ${ }^{23}$ Thus, the acceleration of economic accumulation is the outcome of this social imaginary's prevalence, which has brought forth the belief system that sustains capitalism as a social order seeking endless material progress, i.e. economic growth. Likewise, but from a different perspective, Taylor traces a society's moral order in the shared way in which its members collectively imagine their social existence and expectations, in order to legitimise that order so that they can co-exist. ${ }^{24} \mathrm{He}$ finds that within capitalism the economy, as one of three central imaginaries in modern society - the other two being the public sphere and the citizen-state - is socially conceived as a natural self-regulating order harmonising the private with the public interest. ${ }^{25}$ Ultimately, this is done by reducing the latter to the former - private economic growth is considered as the only possible conception of social progress. However, recognition of the social emphasis on the role of the economy ("the market") is important in itself: it explains the colonizing effect of economic rationality in

\footnotetext{
${ }^{20}$ E.g. Bowrey, G. and Smark, C. "The Influence of Jeremy Bentham on Recent Public Sector Financial Reforms" (2010) 8(1) Journal of New Business Ideas and Trends 25.

${ }^{21}$ Adams, S. et al., "Social Imaginaries in Debate" (2015) 1(1) Social Imaginaries 15.

${ }^{22}$ Castoriadis, C., The Imaginary Institution of Society (Polity Press, 1987).

${ }^{23}$ Castoriadis, C., Figures of the Thinkable, Arnold, H. (transl.) (Stanford University Press, 2007). Weber's verdict was similar: "[n]atural science gives us an answer to the question of what we must do if we wish to master life technically. It leaves quite aside, or assumes for its purposes, whether we should and do wish to master life technically and whether it ultimately makes sense to do so"; Weber, M., "Science as a Vocation" (orig. 1918) (1958) 87(1) Daedalus 111, 122. Indeed, humanity's command over nature was Bacon's primary programmatic aim; Bury, supra. n10, 52.

24 Taylor, C., Modern Social Imaginaries (Duke University Press, 2004), 23.

${ }^{25}$ Taylor thus uses the social imaginary to both trace the roots of and legitimise capitalism as rational which perhaps explains his complete neglect of Castoriadis' earlier work which was quite critical of capitalism.
} 
social relations and the institutional order ${ }^{26}$ through the determination of socially constructed forms in a way that fits the dominant growth-oriented paradigm.

This social framing also brings forth the logic of the "market society", ${ }^{27}$ where the economy is a sphere of private emancipation from the state and where social relations and institutions are largely determined and legitimised by their economic purposes and in economic terms. Thus, concepts like human or natural resources (i.e. work and nature or land), intellectual property (i.e. creativity), opportunity cost (i.e. uncertainty), competition (i.e. relating with others), labour-hours (i.e. time) etc. emerge as symbols of and only make sense within this growth-oriented capitalist imaginary, because they are all conceived as means towards economic growth. Inevitably, parallel to this redefinition of the symbolic order along the lines of an economic logic, institutional structures are then redesigned to reflect and "enact" this order so that a growth-oriented social organisation is created. Thus, the world of ideas can only co-evolve with social practice and structure.

Business organisation is, of course, the primary social sphere where the growth-oriented logic took hold during the transition to capitalism. In this respect, economic historians tend to emphasise two types of "proto-capitalists" as the embryonic carriers of the growth paradigm and therefore of social transformation towards capitalism. ${ }^{28}$ Firstly, the early merchants, who gradually replaced state-controlled trade and eventually privatised mercantilism, were active promoters of what they regarded as national prosperity through the pursuit of domestic and export markets' growth. ${ }^{29}$ They were thus granted quasi-monopoly rights in the form of corporate charters based on the assumption their otherwise private enterprises ultimately served public goals; this indicates a move towards aligning the public interest with private economic gain as envisaged by Taylor above. Secondly, feudal lords are often thought to be first-movers in adopting proto-capitalist production techniques by hiring non-owner wage-labourers and using efficiency-oriented methods in order to maximise output. ${ }^{30}$ While historians disagree on the comparative importance of landowners as opposed to merchants in capitalist transition, it

\footnotetext{
${ }^{26}$ Habermas, J., The Theory of Communicative Action Vol.2: Reason and Rationalisation of Society (Beacon Press, 1984), 154 and 196.

${ }^{27}$ Polanyi, K., The Great Transformation, $2^{\text {nd }}$ ed. (Beacon Press, 2002).

${ }^{28}$ Mielants, E., "Perspectives on the Origins of Merchant Capitalism in Europe" (2000) 23(2) Review (Fernand Braudel Center) 229.

${ }^{29}$ Grampp, W., "The Liberal Elements in English Mercantilism” (1952) 36(4) Quarterly Journal of Economics 465, 473. On the role of early merchants van Zanden, J., The Rise and Decline of Holland's Economy: Merchant Capitalism and the Labour Market (Manchester University Press, 1993) and Levitt, K., Silent Surrender: The Multinational Corporation in Canada (McGill-Queens University Press, 2002).

30 This is primarily argued by Marxist historians; e.g. Brenner, R., "The Origins of Capitalist Development: A Critique of Neo-Smithian Marxism, " (1977) 104 New Left Review 25; Mendels, F., "Proto-industrialization: the First Phase of the Industrialization Process", (1972) 32 Journal of Economic History 241.
} 
seems their roles were rather complementary, as the former were a prime source of finance for the latter, at least until merchants' accumulated sufficient surpluses to become a major source of finance for the private and public economy. ${ }^{31}$ Thus, the surpluses of one sector fed the surpluses of the other, so that a privatised economy emerged which was sustained and whose growth was perpetuated by the ceaseless re-investment of profits. It was those interests combined which promoted and financed canals and railways, the primary capitalist infrastructure, with their savings. ${ }^{32}$ Merchants, in particular, were also instrumental in organizing and financing proto-industrial enterprises, as well as in establishing the financial infrastructure for the Industrial Revolution's take-off in Britain and elsewhere. ${ }^{33}$

As the private economy expanded, proto-capitalists' envisioning of social relations and structures eventually became prevalent so as to define modern society as one where private economic growth is the primary goal and prosperity measure. However, this was by no means a natural progression in the absence of alternatives. ${ }^{34}$ If anything, these proto-capitalists can be regarded as social entrepreneurs whose ideas and practices were aligned with and found fertile ground in the social imaginary described earlier. On that basis, they could flourish and acquire social influence as agents of the idea of economic growth as "progress". The private nature of capitalism's original entrepreneurs does not negate the role the state undertook in the pursuit of growth. For instance, governments were eager to support merchant enterprises, because they saw them as important sources for increasing public revenues through taxing their profits. Similarly, public subsidies facilitated private investment in the infrastructure required for economic expansion. ${ }^{35}$ In short, from an initially embryonic idea of certain private interests, the belief system of the "market-society" came to dominate public policy and economic growth eventually became the primary political objective. As we shall see later (cf part 3), this redefinition of the role of the state as facilitator of the economy is the precursor to the almost complete subjugation of public goals to private economic ones.

\footnotetext{
${ }^{31}$ Grassby, R., "English Merchant Capitalism in the Late Seventeenth Century" (1970) 46 Past and Present 87, at 106; also Mendels, ibid., 166-167. On the historical disagreement see Mielants, supra. n28.

${ }^{32}$ Cottrell, P., Industrial Finance 1830-1914: The Finance and Organization of English Manufacturing Industry (Methuen, 1980).

${ }^{33}$ Price, "What Did Merchants Do? Reflections on British Overseas Trade, 1660-1790" (1989) 49(2) Journal of Economic History 267, 282; Ward, J, The Finance of Canal Building in Eighteenth Century England (Oxford University Press, 1974); MacDonald, L., "Merchants Against Industry: an Idea and Its Origins" (1975) 56(3) Canadian Historical Review 263; Becker, S., "The German Metal Traders before 1914” in: Jones, G. (ed.), The Multinational Traders (Routledge, 1998), 66; Smith, M., The Emergence of Modern Business Enterprise in France, 1800-1930 (Harvard University Press, 2006).

${ }^{34}$ Meiskins Wood, E., The Origin of Capitalism: A Longer View (Verso, 2002).

${ }^{35}$ Indicativelly, Cheng J., States, Intergovernmental Relations, and Market Development (Palgrave Macmillan, 2019), 70 et seq. describes the US political economy in the late 1700s and early 1800 s as a "state-centered illiberal corporate regime."
} 
Expectedly, the law and business organisation law in particular could not but co-evolve with these business-related and wider-societal transformations, in order to support economic expansion. ${ }^{36}$ Mercantilist traders were in need of a legal form that could effectively organise the combination of risk with investment capital from outsiders. The corporation - until then used primarily by public or quasi-public organisations - provided an excellent tool, because it offered a fictitious corporate personality which not only allowed an infinite existence, but also segregated enterprise assets from the ownership of shares. This facilitated the transferability of the latter so as to eventually become an independent marketable asset. ${ }^{37}$ Additionally, incorporation was often complemented by limited liability for investor-shareholders, ${ }^{38}$ who could thus calculate their maximum exposure to business risk in advance. These two features enhanced the attractiveness of investment in those corporations' shares. For merchants, apart from access to outside finance, incorporation also offered a governance structure which allowed them to manage their business with virtually no outside control exercised by such investors.

Similarly to merchant business ventures, large-scale infrastructure projects also required the corporate form in order to attract the necessary capital and take advantage of the organisational advantages of incorporation. Certainly, all those corporations operated on a semi-private basis as their charters were granted and qualified by the state; hence their number was initially relatively limited. However, in them we see the amalgamation of the public and the private economic interest becoming entrenched so as to turn business organisation law - more specifically, corporate law - into a very effective servant of economic growth. Moreover, this organisational change also impacted on the financial infrastructure that came to define "market society", as it facilitated the creation of markets for shares which were further expanded by unchartered entities that mimicked corporations by using trust deeds as vehicles for issuing shares to the public. ${ }^{39}$

Thus, by the mid- $19^{\text {th }}$ century, a significant share of savings was invested in and managed by the private corporate sector, until excess and corruption necessitated regulation for protecting investors. ${ }^{40}$ However, the private economy's momentum was such that the only

\footnotetext{
${ }^{36}$ E.g. Horwitz, M., The Transformation of American Law, 1780-1860 (Harvard University Press, 1977) explains how the law was used and redefined to promote business expansion in the US.

${ }^{37}$ Ireland, P., "Capitalism Without the Capitalist: The Joint Stock Company Share and the Emergence of the Modern Doctrine of Separate Corporate Personality" (1996) 17 Journal of Legal History 41.

${ }^{38}$ Shannon, H., "The Coming of General Limited Liability" (1931) 41(1) Economic Journal 267.

${ }^{39}$ Mirowski, P., "The Rise (and Retreat) Of a Market: English Joint Stock Shares in the Eighteenth Century" (1981) 41(3) Journal of Economic History 559.

${ }^{40}$ Hunt, B., "The Joint-Stock Company in England, 1830-1844" (1935) 43(3) Journal of Political Economy 331.
} 
possible way to regulate was by liberalizing incorporation in exchange for a general framework of accountability and transparency. This was pioneered in Britain which was the first to offer a general grant of all the benefits of incorporation to private business with the enactment of the Joint Stock Companies Act 1844 and the Limited Liability Act 1855; other major jurisdictions sooner or later followed the same path. ${ }^{41}$ This is the genesis of modern corporate law as essentially private law for business, while the role of the state since then has remained supplementary especially as most of corporate law is essentially privately enforced. ${ }^{42}$

However, if in its formative era large business became associated with the corporation, the corporatisation of business organisation law was not uniform in all sectors and in all jurisdictions. For instance, in the US manufacturing sector the corporation dominated from the start, while in Britain, with the exception of large infrastructure projects, enterprises were still organised as partnerships for most of the $19^{\text {th }}$ century. British owner-entrepreneurs retained full control of their businesses and were fully responsible for their debt obligations, as external finance came in the form of loans which were effectively secured by partners' personal assets. ${ }^{43}$ This reflected the important role of partners' social status and, thus, of personal relationships in business transactions; the unlimited liability of partners symbolised business integrity. ${ }^{44}$

However, even in the manufacturing sector the corporate form steadily gained ground as business scale increased. Corporatisation was initially driven by business consolidation though a merger wave in the 1890s in response to increased competition and the need for large capital investment. ${ }^{45}$ Similar trends have been observed in other major European and North American jurisdictions around this time. ${ }^{46}$ As scale and complexity increased, private business could no longer be easily organised on the basis of personal relationships which then had to be substituted by impersonal generally applicable governance rules. ${ }^{47}$ In short, as the private economy grew, there was an increasing demand for corporate law, on the one hand, to shield business assets for ensuring the perpetual existence of the going-concern through profit

\footnotetext{
${ }^{41}$ Pistor, K, Keinan, Y. and Heisterkamp, K., "The Evolution of Corporate Law: A Cross-country Comparison" (2002) 23 University of Pennsylvania Journal of International Economic Law 791, 807-811.

${ }^{42}$ Keay, A. "The Public Enforcement of Directors' Duties: A Normative Inquiry" (2014) 43 Common Law World Review 89, 92-96; Moore, M., Corporate Governance in the Shadow of the State (Hart, 2013).

${ }^{43}$ Bubb, R., "Choosing the Partnership: English Business Organization Law during the Industrial Revolution" (2015) 38 Seattle University Law Review 337.

${ }^{44}$ Pearson, R. and Richardson, D., "Business Networking in the Industrial Revolution" (2001) 4 Economic History Review 657.

${ }^{45}$ Hannah, L. , "Mergers in British Manufacturing Industry, 1880-1918” (1974) 26(1) Oxford Economic Papers 1.

${ }^{46}$ Payne, P., "The Emergence of the Large-scale Company in Great Britain, 1870-1914" (1967) 20(3) Economic History Review 519; Kling, G., "The Long-Term Impact of Mergers and the Emergence of a Merger Wave in PreWorld-War I Germany" (2006) 43 Explorations in Economic History 667.

${ }^{47}$ US business was the first to embrace the corporation, but Europeans also followed the same path; Payne, ibid.
} 
reinvestment and, on the other, to protect outside investors who were not involved in business governance. ${ }^{48}$ If partnerships relied on partners' limited assets, the corporation provided a legal vehicle for limitless pools of capital which served well the social propensity to accumulate with no limits. As economic growth resulted in increasing savings, these found new investment opportunities in corporate stocks in all major sectors. Thus, the corporatisation process of business organisation law was fairly long and not contemporaneous in all sectors of the economy or in all major jurisdictions. ${ }^{49}$ However, incorporation eventually became an essential part of the legal infrastructure, so that modern business organisation law has become almost synonymous with corporate law.

Overall, the corporatisation of business organisation law has not been an accidental development, but an institutional reflection of the social imaginary on which the "growth as progress" paradigm is founded. That is, the social dynamics of capitalism required the capitalist spirit's entrenchment in the institutional structure and in business organisation law more precisely. This has been the legitimacy grounding for offering corporate law to private business. However, if corporate law was initially a tool of merchant social entrepreneurship and economic accumulation, it has now evolved into something much more socially significant. To the extent that corporate law reproduces growth as a primary end, there is a mismatch between business and social needs. This is the root cause of the legitimacy problem business organisation (law) now faces and is discussed next.

\section{The Inverted Relation Between Society and Corporatised Business Organisation Law}

As already mentioned, the causality between economic growth and the corporatisation of business organisation law has not remained unidirectional. We will see here that corporate law is a major institutional feature by which a growth bias in business organisation and in society more widely is imposed and reproduced as a structural problem and irrespective of its consequences. To explain this it is necessary to look a bit more closely at the basic features of corporate law and their impact on business organisation within capitalism. This analysis reveals two important and interrelated developments. The first is that corporatisation is closely

\footnotetext{
${ }^{48}$ Hansmann, H, Kraakman, R. and Squire, R., "Law and the Rise of the Firm" (2006) 119 Harvard Law Review 1335 .

${ }^{49}$ Lamoreaux, N. and Rosenthal, J., "Legal Regime and Contractual Flexibility: a Comparison of Businesses' Organizational Choices in France and the United States During the Era of Industrialization" (2005) 7(1) American Law and Economics Review 28; Guinnane, T. and Martínez-Rodríguez, S., "Choice of Enterprise Form: Spain, 1886-1936” (2018) 34(1) Journal of Law, Economics, and Organization 1.
} 
associated with the rise of the managerial corporation as a self-governed organization which is largely immune from external pressures. Secondly, the managerial corporation is essentially an autonomous private bureaucracy which reproduces the growth ideal; this is the root of the social legitimacy problem of business organisation (law).

\section{A. Corporate Law and Managerialism}

In the previous part it was shown how pre-corporatised business organisation law was a constraint to endless growth due to its emphasis and reliance on entrepreneurs' resources and that the general offering of incorporation rights removed this "growth-break" inbuilt in the legal structure of private business. In fact, the essential default features of corporate law standard in most jurisdictions - are designed to enable infinite growth in several ways.

First, the legal recognition of corporate personality signifies the creation of an entity whose economic base ought to be unaffected by the financial affairs of those who control it and protected from their (mis)conduct. ${ }^{50}$ Simultaneously, corporate law creates a governance framework for preserving and constantly expanding those assets as well as of any returns from their exploitation that may accrue. ${ }^{51}$ This should include directors' duties articulated in accordance with principles like commercial prudence ${ }^{52}$ and loyalty to the corporate person which is vested with its own interests. ${ }^{53}$ The legal techniques used for implementing those governance principles may vary between legal systems, ${ }^{54}$ but once loyalty and prudence are geared towards promoting the corporate interest, it is hard to imagine how this may be interpreted differently to growing the corporate asset-base and profitability without express provision to the contrary in the corporate constitution. This framework is then complemented by the protection offered to shareholders against corporate risk through the limitation of their liability to the level of their investment. This erases any limitation in the capital pooling capacity of the corporation, a well-recognised feature since its early days, but more importantly, it promotes business expansion by facilitating the management - or even the

\footnotetext{
${ }^{50}$ Hansmann, H. and Kraakmann, R., “The Essential Role of Organizational Law” (2000) 110 Yale Law Journal 387.

${ }^{51}$ Blair, M., "Locking in Capital: What Corporate Law Achieved for Business Organizers in the Nineteenth Century" (2003) 51 UCLA Law Review 387

52 Section 174 of the Companies Act 2006 refers to the standard of the "reasonable director".

${ }^{53}$ Section 172(1) of the Companies Act 2006 requires the promotion of the company's success independently of its current shareholders.

${ }^{54}$ For a broad comparative study see Gerner-Beuerle, C, Paech, P. and Schuster, E., Study on Directors' Duties and Liability (European Commission/LSE Enterprise, 2013).
} 
avoidance - of liability risk stemming from increased scale and complexity. ${ }^{55}$ It is, therefore, difficult to exaggerate the growth-propulsion nature of standard corporate law as a vehicle for business organisation.

Certainly, legal form matters little so long as the business entity remains so tightly controlled by an entrepreneur that the distinction between the corporate person and the shareholder effectively disappears. However, as the tendency away from this pattern is built in the structure and incited by the dominant forces in society, one can only expect at least some corporations to expand enough so that their existence cannot be collapsed to that of one or a few entrepreneurs. ${ }^{56}$ What is significant for our purposes is that this process has been the primary cause of the de facto transfer of large corporations' control from shareholder-entrepreneurs to managers that Berle and Means detected in respect of large US corporations in the 1930s and which is since then observed in various degrees and forms in many major jurisdictions. ${ }^{57}$ Without the support of and incentives in business organisation law as discussed above this would have been impossible. Thus, corporate law has been a major contributory to the passage from early entrepreneurial capitalism to modern "managerial capitalism" where economic activity is dominated by the manager-controlled corporation.

In this sense, it is hard to deny that corporate law is essentially managerialist, in that by prioritizing the protection of the corporate entity it entrenches the position of whoever manages it, as long as they further the entity's economic expansion without self-dealing. The "business judgment rule" pioneered by US courts and adopted by jurisdictions as diverse as Germany and Australia, in order to protect corporate boards from retrospective scrutiny of their decisionmaking illustrates this. ${ }^{58}$ Even the ostensibly more shareholder-friendly stance of UK corporate law offers no inferior protection. ${ }^{59}$

This mix of growth-orientation with the protection of managerial autonomy in corporate law is of immense importance once managerial motivations which are known to be primarily

\footnotetext{
${ }^{55}$ Muchlinski, P. "Limited Liability and Multinational Enterprises: a Case for Reform?” (2010) 5(1) Cambridge Journal of Economics 915.

${ }^{56}$ This is actually unavoidable; see infra. n61-64 and text.

${ }^{57}$ Berle, A. and Means, G., The Modern Corporation and Private Property (Macmillan, 1933); Hannah, L., "The 'Divorce' of Ownership from Control from 1900 Onwards: Re-calibrating Imagined Global Trends" (2007) 49(4) Business History 404; Maclean, M., Harvey, C. and Press, J. "Managerialism and the Post-War Evolution of the French National Business System” (2007) 49(4) Business History 531; Brulin, G. and Nilsson, T., "From Societal to Managerial Corporatism" (1991) 12 Economic and Industrial Democracy 327; Odagiri, H, Growth through Competition, Competition through Growth: Strategic Management and the Economy in Japan (Oxford University Press, 1994); Chandler, A., Scale and Scope: Dynamics of Industrial Capitalism (Belknap Press, 1994).

${ }^{58}$ Cohn, S., "Demise of the Director's Duty of Care: Judicial Avoidance of Standards and Sanctions through the Business Judgment Rule” (1983) 62(4) Texas Law Review 591.

${ }^{59}$ Keay, A. and Loughrey, J., "The Concept of Business Judgment” (2019) 39(1) Legal Studies 36.
} 
focused on increasing scale ${ }^{60}$ are also accounted for. It is this mix which allows and fuels business growth with no limitation. If corporate law eliminates internal legal constraints to growth, the resulting managerial organisation has also eradicated external constraints so that managerial capitalism can be seen as an inexorable growth-oriented social system.

More specifically, the interaction of corporate law with competitive forces, pushes markets towards oligopoly, a phenomenon witnessed in most sectors since business organisation law was corporatised. ${ }^{61}$ This has been a major insight by Marxist theorists who explained increasing market concentration and organisational scale as outcomes of competition dynamics. ${ }^{62}$ Ironically, instead of limiting concentration - policy orientation is towards prices as opposed to organisational scale - competition law stimulates it. ${ }^{63}$ This is because, where anticompetitive collusion is prohibited, competitive pressures are then managed through mergers and acquisitions by which dominant oligopolistic corporations emerge and further enhance their market power; indeed the evidence of increasing market concentration is abundant in most sectors. ${ }^{64}$ As a result and due to the corporatisation of business organization law, input and output markets have been to a significant degree fully internalised by the managerial corporation via equity ownership. Where this is not possible or undesirable for strategic purposes, these markets are hierarchically controlled via global supply networks. ${ }^{65}$ Indeed, empirical research on global value chains has revealed that such networks are organised and controlled through various non-ownership methods by powerful oligopolistic corporations who thus reproduce their market power on a global scale in order to reap the benefits of national differences. ${ }^{66}$ Thus, if in the past the managerial corporation could internalise national markets,

\footnotetext{
${ }^{60}$ Marris, R., Managerial Capitalism in Retrospect (Macmillan, 1998); Odagiri, H., The Theory of Growth in a Corporate Economy (Cambridge University Press, 2008) and Odagiri, supra. n56.

${ }^{61}$ No wonder Adam Smith (supra. n16, 754-755) vehemently criticised the chartered corporation as an anticompetitive institution due to the monopoly rights granted to it. However, the growth bias of corporate law should have upset him more.

${ }^{62}$ E.g. Hilferding, R., Finance Capital: A Study of the Latest Phase of Capitalist Development (orig. 1910), ed. Bottomore, T. (Routledge \& Kegan Paul, 1981).

${ }^{63}$ Blonigen, B., and Pierce, J., "Evidence for the Effects of Mergers on Market Power and Efficiency, NBER NBER Working Paper No. 22750, October 2016.

${ }^{64}$ Griffin, C., "The Hidden Cost of M\&A" (2018) 70(1) Columbia Business Law Review 70; Kamerbeek, S., "Merger Performance and Efficiencies in Horizontal Merger Policy in the United States and the European Union" (2010) 1(1) Journal of Advanced Research in Law and Economics 16; Blonigen, B. and Pierce,J., Evidence for the Effects of Mergers on Market Power and Efficiency, NBER Working Paper (No.w22750, October 2016).

${ }^{65}$ Humphrey, J. and Schmitz, H. "Governance in Global Value Chains" (2001) 32(2) IDS Bulletin 19; Levy, D., "Hegemony in The Global Factory: Power, Ideology, and Value in Global Production Networks" (2005) 1 Academy of Management Proceedings C1; Sturgeon, T., Van Biesebroeck, J. and Gereffi, G., "Value Chains, Networks and Clusters: Reframing the Global Automotive Industry" (2008) 8 Journal of Economic Geography 97.

${ }^{66}$ For a systematic review of the extensive literature in this field see Bair, J., "Global Capitalism and Commodity Chains: Looking Back, Going Forward" (2005) 9(2) Competition and Change 153.
} 
it can now do the same on a global scale with or without the use of direct ownership and thus further entrench its economic and social power.

On the other hand, for over fifty years various scholars have been expressing their expectation that managers, though effectively protected by corporate law, could still be constrained by capital market pressures and the market for corporate control rights in particular. ${ }^{67}$ More recently, these expectations have even included the idea that the managerial corporation could become "socialised" - i.e. aligned with social needs - through the market for corporate securities. ${ }^{68}$ Indeed, such hopes have intensified over the years, especially as capitalist accumulation becomes increasingly financialised by relying on profit-making by way of asset-price speculation rather than production investment. ${ }^{69}$ Thus, while not a new phenomenon, ${ }^{70}$ since the 1980 s whole corporations or their component parts have become fully commodified via the market for corporate control and turned to both objects and subjects of financial speculation based on their stock market valuations. Simultaneously, the reform of savings systems which are now invested in stock markets has also resulted in the rise of institutional investors as dominant stock market players who are expected to constrain managerial power. This expectation is more pronounced in the UK and the US, while other jurisdictions also follow suit in various degrees. ${ }^{71}$ These developments even led prominent observers, like Jensen, to claim that the large managerial corporation would eventually disappear by returning within the control of shareholders. ${ }^{72}$

However, as Cheffins confirmed recently, these hopes are still to materialise ${ }^{73}$ and this is not surprising given that the very conception of the corporation as a collection of assets available for financial speculation has itself emanated from the 1960s managerial practice of

\footnotetext{
${ }^{67}$ The seminal work is Manne, H., "Mergers and the Market for Corporate Control" (1965) 73(2) Journal of Political Economy 110.

${ }^{68}$ Hawley, J. and Williams, A., The Rise of Fiduciary Capitalism: How Institutional Investors Can Make Corporate America More Democratic (University of Pennsylvania Press, 2000); Monks, R., The New Global Investors: How Shareowners Can Unlock Sustainable Prosperity Worldwide (Wiley, 2001).

${ }^{69}$ Epstein, G. (ed.), Financialization and the World Economy (Edward Elgar, 2005); Dore, R., "Financialization of the Global Economy" (2008) 17 Industrial and Corporate Change 1097; Dixon A., Sorsa, V., "Institutional Change and the Financialisation of Pensions in Europe" (2009) 13 Competition \& Change 347; van der Zwan, N., "Making Sense of Financialization" (2014) 12(1) Socio-Economic Review 99.

${ }^{70}$ Armour, J. and Cheffins, B., "The Origins of the Market for Corporate Control" (2014) 5 University of Illinois Law Review 1835.

${ }^{71}$ Chizema, A., "Early and Late Adoption of American-Style Executive Pay in Germany: Governance and Institutions" (2010) 45 Journal of World Business 9.

72 Jensen, M. "Eclipse of the Public Corporation" (1989) 67 Harvard Business Review 61. Organisational theorists were similarly (mis)led to believe that global capitalism would transform business into a de-bureaucratised network-based organisation that would be better suited to the emergence of the "knowledge economy"; cf n94-98 and text.

${ }^{73}$ Cheffins, B., The Public Company Transformed (Oxford University Press, 2019).
} 
building corporate conglomerates through speculative mergers and acquisitions. ${ }^{74}$ This can indeed be understood as a managerial effort to bring capital markets within the managerial organisation. Nonetheless, the reversal of this trend in the 1980s with the break-up of conglomerates has been wrongly interpreted as an assertion of financial investor power over managers. As shown by Bhagat et al. managers and activist investors worked hand-in-hand in using the market for corporate control to achieve complementary strategic and financial objectives. ${ }^{75}$ Thus, the outcome has been more focused, but still oligopolistic managercontrolled corporations, while investors have received large takeover premia financed by asset sales and redundancies. ${ }^{76}$

In fact, this is not the first time managers have been able to accommodate and work with financial interests without surrendering their dominant role. Indeed, Brandeis has demonstrated the compatibility of managerial control and financial capital since 1914, the era when the dominance of the managerial corporation was first established. ${ }^{77}$ More recently, Duménil and Lévy have also documented this symbiosis of financial and corporate capital, which was temporarily interrupted by the post-Great Depression and Post-War corporatist compromise with workers in the context of supportive government policies. ${ }^{78}$ However, this politically sponsored compromise has been unravelling again since the 1980s, the modern era of corporate financialisation, as managers have been able to use their power in order to once again align corporate (and their own) goals with the financialised mode of wealth accumulation. ${ }^{79}$ In this context, the revelation by Armour and Cheffins that the active market for corporate control is not a recent phenomenon, but was also present in the early 1900s, when the managerial corporation first emerged, is of no surprise. ${ }^{80}$

That financialisation and managerialism are not incompatible is also illustrated by the manner in which growth via asset speculation has been turned by top managers at least to more of an opportunity than a challenge. For instance, one would expect the management of Apple,

\footnotetext{
${ }^{74}$ Knaffo, S. and Dutta, S. "Patient Capital in the Age of Financialized Managerialism" (2016) 14(4) SocioEconomic Review 771.

75 Bhagat, S., Shleifer, A. and Vishny, R., "Hostile Takeovers in the 1980s: The Return to Corporate Specialization" (1990) 21 Brookings Papers on Economic Activity 1.

76 Lazonick, W. and O'Sullivan, M. "Maximizing Shareholder Value: A New Ideology for Corporate Governance" (2000) 29 Economy and Society 13.

${ }^{77}$ Brandeis, L., Other People's Money and How the Bankers Use It (Stokes, 1914).

78 Duménil, G. and Lévy, D., "Neoliberal Managerial Capitalism" (2015) 44(2) International Journal of Political Economy 71.

${ }^{79}$ Boyer, R., "From Shareholder Value to CEO Power: The Paradox of the 1990s" (2005) 9(1) Competition \& Change 7; Froud, J., Johal, S., Leaver, A. and Williams, K., Financialization and Strategy: Narrative and Numbers (Routledge, 2006).

${ }^{80}$ Armour and Cheffins, supra. n70.
} 
the largest quoted US corporation, to be among the most constrained by outside investors. Indeed, in 2012 it was targeted by Carl Icahn, the notorious activist investor, for the purpose of forcing the distribution of its gigantic cash holdings to shareholders. Icahn eventually sold his stake after a generous share buy-back programme was indeed implemented, but Apple's cash fund - invested in government and private assets - has continued to expand and already exceeds 280 billion dollars notionally constituting the world's largest investment fund; ${ }^{81}$ a clear illustration of financialised managerialism. In fact, Apple's case is not exceptional, but it simply reflects a general trend since the 1990s, so that non-financial corporations currently hold unprecedented levels of cash reserves. ${ }^{82}$ If one accepts Jensen's (1989) own assertion that excess cash-flow is one of the primary indicators of managerial power, the managerial corporation is still very much with us. Certainly, in the absence of corporatist regulation, managers have been more willing to entertain financial capital's rather than labour's expectations by increasing profit distributions to shareholders at the expense of wage income. The "growth as progress" ideal does not apply to all segments of society equally.

However, even in this redefinition of priorities there is a managerial interest, due to the proliferation of equity-based pay for top executives. The latter have been using their discretionary power over corporate cash-flow to manipulate share prices through share repurchases and thus gain together with shareholders. ${ }^{83}$ That average CEO pay has been rising since the 1980s is a clear indication of how managers' interests benefit from the financialised mode of accumulation and entrench themselves against outside control while continuing to pursue corporate growth. All this is despite some evidence that corporate boards have become more active in overseeing management following extensive corporate governance reforms aimed at strengthening the role of non-executive directors. ${ }^{84}$ As the empirical literature on intra-corporate relation dynamics shows, executive managers and CEOs in particular are still able to dominate the selection and conduct of non-executive directors so long as failure is not

\footnotetext{
${ }^{81}$ Davies, R., “Apple Becomes World's First Trillion-Dollar Company”, The Guardian, 2 August 2018 (available at https://www.theguardian.com/technology/2018/aug/02/apple-becomes-worlds-first-trillion-dollarcompany).

${ }^{82}$ Sánchez, J. and Yurdagul, E., "Why Are Corporations Holding So Much Cash?", Federal Reserve Bank of St.Louis Regional Economist, 1 January 2013 (available at https://www.stlouisfed.org/publications/regionaleconomist/january-2013/why-are-corporations-holding-so-much-cash); Brockman, P. and Chung, D., "Managerial Timing and Corporate Liquidity: Evidence from Actual Share Repurchases" (2001) 61(3) Journal of Financial Economics 417;

${ }^{83}$ Lazonick, W., "The Value-Extracting CEO: How Executive Stock-Based Pay Undermines Investment in Productive Capabilities", Working Paper No.54, Institute for New Economic Thinking, 2016.

${ }^{84}$ Cheffins, supra. n73, 307 et seq.
} 
blatantly obvious. ${ }^{85}$ Thus, even in the financialised economy CEOs continue to reward themselves on the basis of organisational size and the social influence this confers. ${ }^{86}$ Finally, that the managerial corporation is still dominant is also verified by the steady increase of managerial employment over the whole period when the shareholder revolution was supposed to be taking place. ${ }^{87}$

If investor capitalism has not undone managerial capitalism in the US, the powerhouse of financialised accumulation, it is hard to imagine how it may have done so elsewhere. In fact, we may already be witnessing a new trend in managerial entrenchment practice, as the issuing of shares to public investors with restricted governance rights is becoming increasingly common, especially among technology firms; Lynn Stout has called these corporations "neomanagerialist". ${ }^{88}$ The most extreme example of this practice of keeping the stock market at bay is the recent listing of Snap Inc. with the offering of merely non-voting shares. ${ }^{89}$ Simultaneously, the number of corporations interacting with the stock market has been decreasing as a result of merger activity and because innovative market entrants prefer to be taken over by incumbent oligopolists than to seek their independent listing. ${ }^{90}$ Thus, even "grassroots" innovation seems to be feeding the managerial corporation which has the resources to capture and exploit it in order to further entrench its market power.

Overall, corporatised business organisation law has enabled the managerial corporation to bring external "market" constraints largely within its control; the "market" economy is therefore more of an illusion and resembles more a managed rather than a competitive system. What may differ in the financialised mode of managerialism from its post-War predecessor is that the balance of corporate surplus distribution has titled away from wage earners and in favour of financial and corporate elites. ${ }^{91}$ Certainly, this is a problem in itself, but resolving it

\footnotetext{
${ }^{85}$ Westphal, J. and Zajac, E., "Who Shall Govern? CEO/Board Power, Demographic Similarity, and New Director Selection" (1995) 40(1) Administrative Science Quarterly 60; Westphal, J. and Khanna, P., "Keeping Directors in Line: Social Distancing as a Control Mechanism in the Corporate Elite" (2003) 48(3) Administrative Science Quarterly 361; Benton, R., "Corporate Governance and Nested Authority: Cohesive Network Structure, ActorDriven Mechanisms, and the Balance of Power in American Corporations" (2016) 122(3) American Journal of Sociology 661; Benton, R., "Brokerage and Closure in Corporate Control: Shifting Sources of Power for a Fractured Corporate Board Network" (2018) Organization Studies 1.

${ }^{86}$ Peetz, D., "An Institutional Analysis of the Growth of Executive Remuneration” (2015) 57(5) Journal of Industrial Relations 707.

87 Goldstein, A., "Revenge of the Managers: Labor Cost-Cutting and the Paradoxical Resurgence of Managerialism in the Shareholder Value Era, 1984 to 2001” (2012) 77(2) American Sociological Review 268.

${ }^{88}$ Stout, L., "On the Rise of Shareholder Primacy, Signs of Its Fall, and the Return of Managerialism (in the Closet)" (2013) 36 Seattle University Law Review 1169-1185, 1182.

${ }^{89}$ Gordon, Z., "A Snapshot of Dual-Class Share Structures In The Twenty-First Century: A Solution to Reconcile Shareholder Protections With Founder Autonomy” (2018) 68 Emory Law Journal 335.

${ }^{90}$ Doidge, C., Kahle, K., Karolyi, A. and Stulz, R., "Eclipse of the Public Corporation or Eclipse of the Public Markets?" (2018) 30(1) Journal of Applied Corporate Finance 8.

${ }^{91}$ Piketty, T., Capital in the Twenty-First Century (Harvard University Press, 2014).
} 
would still not reverse the protection of managerialist growth corporate law offers. However, and more importantly for our purposes, the impact of corporate law as the legal infrastructure of managerial capitalism is much wider, because by protecting managerial autonomy it has also led to the inversion of the relationship between business organisation (law) and society. This argument is presented next.

\section{B. Managerial Bureaucracy and Business Organisation Law as a Structural Problem}

We saw earlier that in early entrepreneurial capitalism the pursuit of economic growth served the social ideal of "progress", a legitimate arrangement at the time as the negative consequences were still largely unknown. However, while this legitimacy basis is largely outdated today, business organisation still remains attached to it, so that there is a mismatch with society's need to meet current challenges. It will be argued here that this is a legitimacy problem of business organisation associated with what was discussed above about the managerial corporation and corporate law as its legal platform and protector. Crucial are two structural factors which have essentially inverted the relationship of society with business organisation (law), as the former is placed at the service of economic growth and of business organisation as its generator.

The first factor is that managerial capitalism is institutionally supplemented by an inexorable shift away from personal relations and towards bureaucracy as an organisational form where impersonal, hierarchical and "rationally" devised governance methods prevail. This is because increasing organisational size necessitates the adoption of hierarchical and, therefore, bureaucratic organisational elements. ${ }^{92}$ Thus, the managerial corporation is in effect a private self-controlled bureaucracy as its objectives are primarily set internally by its own management. Since Max Weber first began to analyze its nature, bureaucracy has been recognised - even by his critics - as an organisational mode reliant on conformism and the exclusion of radical reflection about its organisational objectives once those are set. ${ }^{93}$ Thus, in the absence of effective outsider constraints, once managerial incentives are aligned with

\footnotetext{
${ }^{92}$ Max Weber was the first to associate large organisational scale with bureaucracy; Weber, M., Economy and Society (1922), Roth, G. and Wittich, C. (eds.) (University of California Press, 1978), 221 and 224; also Dimock, M. and Hyde, H., Bureaucracy and Trusteeship in Large Corporations (US Government Printing Office, 1940), 36. Similarly, Simon, H., Administrative Behavior (Free Press, 1976) associates bureaucratisation with organisational size and complexity.

${ }^{93}$ Merton, R., Social Theory and Social Structure (Free Press, 1968), 249 et seq.. Conformity is promoted through task-setting and incentive manipulation; see Edwards, R., Contested Terrain: the Transformation of the Workplace in the Twentieth Century (Basic Books, 1979), esp. 128-129 and 148-149.
} 
promoting growth, the latter is instituted as the primary organisational goal and the bureaucratic corporation becomes entangled in a self-reinforcing, growth-oriented organisational loop: growth expands managerial control and managerial control promotes growth. Weber's own potential solution to this problem with bureaucracy - he famously described it as an "iron cage" - was the charismatic entrepreneur who could redefine organisational objectives. ${ }^{94}$ This is obviously more of a hope than a realistic option, especially as this type of (social) entrepreneur does not seem to exist in the managerial corporation. The incentives of CEOs, even of the socalled "imperial" type, ${ }^{95}$ are too aligned with growth as a way of increasing power and individual returns to even hope for radical divergence from this objective. Charisma is thus a mere contingency which may not even occur because of structural inhibiting factors; the managerial corporation seems to have "stagnated" in a self-expansionist mode.

Undoubtedly, some organisation theorists ${ }^{96}$ have questioned the bureaucratisation thesis arguing that business is increasingly abandoning hierarchical relationships as it moves away from Taylorist production and towards the "knowledge economy" which relies on worker creativity and autonomy rather than obedience. ${ }^{97}$ However, this view is empirically contested and largely utopian as the managerial organisation has been capable of accommodating even this internal pressure very effectively. Research on high-tech start-ups, the core players in the knowledge economy, has shown that such firms face clear bureaucratisation pressures as they grow and age. ${ }^{98}$ More general organisational research has also revealed how managerial authority structures are imposed via the "project management" technique by which, what is marketed as de-bureaucratisation, is effectively total re-bureaucratisation controlled by top management through deeper cultural rather than procedural mechanisms. ${ }^{99}$ Such "soft" control structures using "self-managed" teams have been recognised for some time now as a tighter and more effective method of compliance with top-down values and goals, because workers

\footnotetext{
${ }^{94}$ Weber, supra. n17, 123; Weber, supra. n92, 241, 1111, 1115. See also Mommsen, W., "Toward the Iron Cage of Future Serfdom? On the Methodological Status of Max Weber's Ideal-Typical Concept of Bureaucratization" (1980) 30 Transactions of the Royal Historical Society 157.

${ }^{95}$ Cheffins, B., "The Corporate Governance Movement, Banks, and the Financial Crisis" (2015) 16(1) Theoretical Inquiries in Law 1.

${ }^{96}$ Adler, P. "Market, Hierarchy, and Trust: The Knowledge Economy and the Future of Capitalism" (2001)

12(2) Organization Science 215. Unger, R., The Knowledge Economy (Verso, 2019).

${ }^{97} \mathrm{I}$ am grateful to one of the anonymous reviewers for this point.

${ }^{98}$ Baron, J., Burton, M. and Hannan, M. "Engineering Bureaucracy: the Genesis of Formal Policies, Positions and Structures in High-Technology Firms" (1999) 15(1) Journal of law economics \& organization 1.

${ }^{99}$ Hodgson, D., "Project Work: The Legacy of Bureaucratic Control in the Post-Bureaucratic Organization" (2004) 11(1) Organization 81.
} 
tend to fully internalise them. ${ }^{100}$ Thus, if anything, the modern version of managerialism is even more controlling than its Taylorist predecessor.

The second structural factor - related to the first - is that, as bureaucratic business organisation exercises its power over the enlarged private economy, it also uses it to impose its own goals upon society as well. The channels through which such corporate dominance is exercised are numerous and multidimensional. For instance, as mentioned above, intraorganisationally the socialisation of those employed by corporate bureaucracies is directly manipulated through incentives and sanctions, in order to conform to organisational patterns which can then become so inflexible as to foster tunnel vision. ${ }^{101}$ To some degree at least, it is expected individuals will carry the corporate value system outside the corporation too. On the other hand, various forms of extra-organisational domination also exist, spanning from using various channels of political influence ${ }^{102}$ to sponsoring academic legitimation ${ }^{103}$ or manipulating consumer behaviour by enhancing materialistic tendencies that drive demand and growth. ${ }^{104}$ Business organisation can exercise its social power to impose its own categories of thought and perception of the world upon the individual within and outside of it. By internalizing those categories, the individual perceives the dominant social paradigm as the legitimate vision of the world and thus overlooks alternative logics. ${ }^{105}$ In other words, the intraorganisational loop described earlier becomes a social loop recycling and enhancing the capitalist social imaginary subjugating any alternatives. ${ }^{106}$ Thus, by creating the preconditions for large scale business and by effectively protecting managerial and thus corporate autonomy, business organisation law is a fundamental part of the institutional framework supporting this loop. Corporate law is a central institution of the growth paradigm and its role is ultimately to reproduce and expand it.

Certainly, some emphasise the ability of open public discourse to remedy such problems by questioning the legitimacy of established norms like those determined by the social loop

\footnotetext{
100 Barker, J., "Tightening the Iron Cage: Concertive Control in Self-Managing Teams" (1993) 38(3) Administrative Science Quarterly 408.

${ }^{101}$ Bureaucratic manipulation of behaviour can be so intense that Merton, supra. n93, 252, even uses the term "occupational psychosis".

102 Schuler, D., Rehbein, K., and Cramer, R. "Pursuing Strategic Advantage through Political Means: A Multivariate Approach" (2002) 45(4) Academy of Management Journal 659.

${ }_{103}$ Mirowski, P., Never Let a Serious Crisis Go to Waste. How Neoliberalism Survived the Financial Meltdown (Verso, 2013), 337; Styhre, A., "A Managerial Revolution in Reverse: Finance Market Control of the Corporation and the Triumph of the Agency Theory Model" (2015) 10(1) Management \& Organizational History 71, 77-81. ${ }^{104}$ O'Shaughnessy, J. and O'Shaughnessy, N., "Marketing, the Consumer Society and Hedonism" (2002) 36(6) European Journal of Marketing 524.

105 Bourdieu, P., "Social Space and Symbolic Power" (1989) 7(1) Sociological Theory 14.

106 This is quite similar to what Giddens calls "circuits of reproduction"; Giddens, A., The Constitution of Society (Polity Press, 1984), 190.
} 
analyzed here. ${ }^{107}$ However, this presupposes a social order which allows this discourse to actually happen free from institutional bias or subversion in the first place - that is, it assumes away the impact of phenomena like corporate social power. Indicatively, that public discourse on environmental issues only intensified once the latter created business risks and opportunities (i.e. it made business sense) or that, when it did, the dominant policy norm refers to "sustainable growth" 108 confirms such claims are more tautological than radical and that structural solutions are indeed necessary.

To the extent - and it seems to be quite significant - that corporatised business organisation law is a structure framing public discourse, it is essential that it is (re)formed in a way that its growth bias and subversive tendencies are minimised. It is in this context and on this basis that the legitimacy of business organisation and of corporate law as its legal structure ought to be evaluated. More specifically, if the normative supremacy of economic growth needs to be institutionally curtailed and relegated to an inferior order, some grounding for corporate law reform in this direction must be offered in the form of a corporate purpose beyond growth. This will allow the resolution of the legitimacy problem caused by the current mismatch between business and societal objectives. The first question then is whether such a normative basis for corporate law can indeed be formulated which could then inform reform policy.

\section{The Need for a New Business Legitimacy and the Growth Bias in Corporate Theory}

The discussion will now explore whether the major theoretical strands in corporate scholarship can offer guidance in restoring business legitimacy in the fashion suggested above. As already mentioned, this would require a norm which lies outside corporate law's growth orientation. It will be shown that the colonizing effect of economic determinism has been so pervasive that the debate on corporate legitimacy has been deeply affected by it; corporate law is above all legitimised as a growth-oriented institution. Moreover, even where scholarship attempts to break away from this narrow framing of the normative debate, it stumbles on the structural problems discussed above and reverts back to some nuanced form of economic logic.

\footnotetext{
${ }^{107}$ Barreyro, M., "The Purest Form of Communicative Power: A Reinterpretation of the Key to the Legitimacy of Norms in Habermas's Model of Democracy" (2018) 25(3) Constellations 459; Crouch, C., The Strange Non-death of Neo-liberalism (Polity Press, 2011) also contemplates social critique can effect corporate conduct.

${ }^{108}$ E.g. CDP, Higher Ambitions, Higher Expectations: Europe Report 2018 (CDP, 2019) available at https://www.cdp.net/en/research. For a critique see Wanner, T., “The New 'Passive Revolution' of the Green Economy and Growth Discourse: Maintaining the 'Sustainable Development' of Neoliberal Capitalism” (2015) 20(1) New Political Economy 21.
} 
Certainly, corporate law scholarship had remained quite immune from the influence of economic logic for some time; lawyers' dominant role in the field and their unfamiliarity with economic notions is certainly an explanation. However, the need for legitimising the private corporation's role within capitalism increasingly required new analytical tools concomitant with private economic purposes. The general public interest as a basis for corporate legitimacy was unsuitable for private business and had to be adapted to the capitalist logic through its redefinition as (private) wealth maximisation. Traditional principles of legal legitimacy like the public interest, fairness, justice or equity are not economically quantifiable so they had to be replaced by other economic ones - e.g. profit, cost and efficiency - to fit the socially prevalent paradigm.

The legal field's colonisation by economics began with the marriage of the two disciplines within the Chicago School, after Coase opened a new road towards explaining the existence of the corporate hierarchy and the purpose of legal rules. ${ }^{109}$ Posner consummated the marriage by offering himself as the first spouse from the legal field. ${ }^{110}$ Since then, "law and economics" has evolved into an incredibly elaborate and comprehensive analysis of, not only how the corporation functions, but also how it ought to function. These normative claims, faithful to their methodological tradition, now offer a full theoretical legitimacy of the corporation within a positivist economics and, thus, independently of any sort of social process. That being so, it is rather surprising - from a determinist perspective at least - that such a common root has eventually led to two distinct and competing factions which will be termed here as the "orthodox" and the "progressive", the latter being mostly a euphemism.

In orthodox scholarship the corporation is no more than a structural part of the Walrasian tâtonnement ${ }^{111}$ where organisational trial and error eventually leads to general equilibrium. This is done through a trade-off between the market and the (corporate) hierarchy, as originally envisaged in the Coase theorem ${ }^{112}$ and further elaborated by Williamson's fully fledged transaction cost theory of the firm. ${ }^{113}$ Economic organisation thus consists of a fine balance between activity planned by profit-maximising hierarchies (firms) and non-hierarchical market exchange. Even the managerial incentive-misalignment problem prioritizing growth over

\footnotetext{
${ }^{109}$ Coase, R., "The Nature of the Firm" (1937) 4(16) Economica 386 and "The Problem of Social Cost" (1960) 3 Journal of Law and Economics 1.

${ }^{110}$ Posner, R., Economic Analysis of Law (Little, Brown and Company, 1973).

111 The term describes the process by which the market clears as demand matches supply.

${ }^{112}$ Coase, supra. $\mathrm{n} 110$.

${ }^{113}$ Williamson, O., Markets and Hierarchies: Analysis and Antitrust Implications: A Study in the Economics of Internal Organization (Free Press, 1975) and The Economic Institutions of Capitalism: Firms, Markets, Relational Contracting (Free Press, 1985).
} 
profit, which could derail the whole scheme, has been eventually "resolved" by Alchian ${ }^{114}$ who introduced evolutionary theory in order to claim that competition will cleanse the market from non-maximising firms. The model was finally completed in the extremely influential paper by Jensen and Meckling, ${ }^{115}$ where for the first time a comprehensive theorisation of the corporation was accomplished.

So, within this framework the corporation is and ought to be a profit-maximiser as managers serve shareholder interests, either because of appropriately designed contractual incentives or because, where those fail, the market for corporate control as originally described by Manne ${ }^{116}$ will be an effective corrective mechanism. ${ }^{117}$ The irony is that in this imagery, the corporation as a hierarchy is justified by being completely erased from the picture, in order to elevate contractual arrangements representing the market as the sole coercion mechanism. But this is no coincidence, because otherwise it would be incompatible with the basic assumption of positivist economics that the market is the natural state of affairs; market efficiency and through it the efficient corporation as a profit-maximiser is the theoretical medium ensuring maximum economic growth as the primary measure of social welfare. ${ }^{118}$ Human nature enters the picture only as the homo eeconomicus, the a-social and a-historical persona who is fully and permanently determined by economic rationality, just like the corporation is as well.

Once this paradigm was complete, corporate law scholars did not take long to start adapting in their minds the whole of corporate law so as to legitimise it in capitalist terms. The shareholder-centred corporate objective is there to ensure profit maximisation, managers' interests should be linked with the (efficient) market for shares which determines the "real" price of the corporation, and corporate "law" is simply of contractual nature (default rules) in order to exclude the possibility of government interference with the market's invisible hand. ${ }^{119}$ As Chen and Hanson rightly observe, a whole system of corporate law schemas has been created, in order to offer legitimacy to an ideologically charged construct which, once closely

\footnotetext{
${ }^{114}$ Alchian, A., "Uncertainty, Evolution and Economic Theory" (1950) 58 Journal of Political Economy 211.

115 Jensen, M. and Meckling, W., "Theory of the Firm: Managerial Behavior, Agency Costs and Ownership Structure" (1976) 3(4) Journal of Financial Economics 305.

116 Manne, supra. n67.

117 Gilson, R., "A Structural Approach to Corporations: The Case Against Defensive Tactics in Tender Offers" (1981) 33 Stanford Law Review 819.

${ }_{118}$ Posner, R., "The Ethical and Political Basis of the Efficiency Norm in Common Law Adjudication" (1980) 8 Hofstra Law Review 487. For critical responses against efficiency's dubious normative value see Dworkin, R., "Why Efficiency? - A Response to Professors Calabresi and Posner" (1980) 8(3) Hofstra Law Review 563; Malloy, R., "Is Law and Economics Moral? Humanistic Economics and a Classical Liberal Critique of Posner's Economic Analysis" (1990) 24 Valparaiso University Law Review 147.

119 The list of scholarship is endless but the most influential and comprehensive work is Easterbrook, F. and Fischel, D., The Economic Structure of Corporate Law (Harvard University Press, 1996).
} 
examined, is simply similar to a magical illusion covering up an economic distribution mechanism favouring powerful corporate interests. ${ }^{120}$

Certainly, this illusion does not work on everyone, as not all scholars adhere to the "freemarket" capitalism ideal. "Progressive" economic determinism - spanning, usually implicitly, between Keynesian or behavioural economics ${ }^{121}$ and a Marxist analysis ${ }^{122}$ - has offered the basis for an influential critique of the market-based corporate law model outlined above. While rather diverse, these viewpoints still converge on certain aspects so as to form their own corporate law illusions. A typical launching point from which the deconstruction of orthodox magic begins is the "reality" of externalities. ${ }^{123}$ More importantly, since share markets cannot be efficient due to informational asymmetries or investors cognitive constraints, the market for corporate control creates the wrong incentives and simply redistributes wealth in favour of target companies' shareholders or facilitates the building of managerial empires. ${ }^{124}$ Once the market cannot ensure the efficiency of the corporation, it is necessary to bring regulatory controls in the picture to ensure corporate governance mitigates externalities by balancing wealth distribution. ${ }^{125}$ Ultimately, resolving the distributional problem will increase corporate efficiency and maximise (social) wealth. ${ }^{126}$

In this sense, after closer scrutiny this regulatory purpose does not appear too different from the orthodox corporate law one. The two factions simply use different assumptions which expectedly determine their normative propositions; in orthodox corporate law the distributional issue does not even arise - it is automatically resolved by the equilibrating market - whereas in

\footnotetext{
${ }^{120}$ Chen, R. and Hanson, J., "The Illusion of Law: The Legitimating Schemas of Modern Policy and Corporate Law (2004) 103(1) Michigan Law Review 1.

${ }^{121}$ Indicatively, see Blair, M. and Stout, L., "Trust, "Trustworthiness, and the Behavioral Foundations of Corporate Law" (2001) 149(6) University of Pennsylvania Law Review 1735; Greenfield, K., "Using Behavioral Economics to Show the Power and Efficiency of Corporate Law as Regulatory Tool" (2002) 35 University of California Davis Law Review 581.

${ }^{122}$ E.g. Villiers, C., "Post-Crisis Corporate Governance and Labour Relations in the EU (and Beyond)" (2014) 41(1) Journal of Law and Society 73; Talbot, L., "Trying to Save the World with Company Law? Some Problems" (2016) 36(3) Legal Studies 513.

${ }^{123}$ Mitchell, L., Corporate Irresponsibility - America's Newest Export (Yale University Press, 2001), chapter 2; Greenfield, K., "September 11 and the End of History for Corporate Law" (2002) 76 Tulane Law Review 1409.

${ }^{124}$ E.g. Shleifer, A. and Summers, L., "Breach of Trust in Hostile Takeovers" in Auerbach, A. (ed.), Corporate Takeovers: Causes and Consequences (University of Chicago Press, 1988); Singh, A., "Take-overs, Economic Natural Selection and the Theory of the Firm" (1975) 85 Economic Journal 497;

${ }^{125}$ Coffee, J., "Regulating the Market for Corporate Control: a Critical Assessment of the Tender Offer's Role in Corporate Governance", (1984) 84(5) Columbia Law Review 1145; Greenfield, K., The Failure of Corporate Law - Fundamental Flaws and Progressive Responsibilities (University of Chicago Press, 2006); Galanis, M., "Vicious Spirals in Corporate Governance - Mandatory Rules for Systemic (Re)Balancing" (2011) 31(2) Oxford Journal of Legal Studies 327.

${ }^{126}$ Keay, A., "Ascertaining the Corporate Objective: An Entity Maximisation and Sustainability Model" (2008) 71(5) Modern Law Review 663; Attenborough, D. "Giving Purpose to the Corporate Purpose Debate: an Equitable Maximisation and Viability Principle" (2012) 32(1) Legal Studies 4.
} 
the progressive version, the presence of externalities is resolved via efficient regulatory intervention. The intended outcome remains the same and it is organisational efficiency as a means towards achieving economic accumulation as the primary end. This type of progressive corporate law is used instrumentally to ensure and justify the maximisation of economic profit, as an unquestionable end in itself, which then has to be efficiently distributed among corporate stakeholders in order to avert inefficient wealth transfers. The corporation thus retains its role as a facilitator of general economic equilibrium and progressive corporate law remains as immersed in economic determinism and the growth paradigm as its orthodox opponent. More significantly, when it comes to the risks of capitalist accumulation, whether those are social, environmental or of any other nature, the very concept of externality denotes that there is a monetary value for each one of them. This is equivalent to the most extreme subjection of social rationality to economic determinism; to use Castoriadis' terminology, it is as pseudorational as orthodoxy.

Admittedly, there are scholars who have suggested that the debate on the legitimacy of corporate law has to open up to more fundamental issues, such as the compatibility of profit with social or public goals and have sought to "socialise" the corporation via enhanced state 127 or worker control rights. ${ }^{128}$ Even such claims, though attractive on the surface, suffer from contradictions which prevent them from offering a viable alternative proposition to the mere distributional one.

Firstly, where it is assumed that state control is essentially the solution for taming the "corporate beast", the fact that corporate law is essentially the product of the state anyway is ignored. ${ }^{129}$ If the state could be the agent of a radical top-down change, it would have implemented it already to deal with the social risks of capitalist accumulation. Secondly, replacing shareholder control rights with those of workers as the primary corporate steering power is founded on the assumption that a labour-managed bureaucracy will ignore accumulation and pursue other social goals. However, such propositions offer no elaborate explanation as to how this is possible. If anything, the experience of worker control over the still bureaucratic corporation at best leads to a more nuanced and egalitarian, if not accelerated,

\footnotetext{
${ }^{127}$ A classic work calling for the state to introduce public interest concerns, defined as essentially stakeholder interests, in corporate law is Parkinson, J., Corporate Power and Responsibility: Issues in the Theory of Company Law (Oxford, 1995). For a more recent radical formulation of a similar state-sponsored solution see Bavoso, V., "The Corporate Law Dilemma and the Enlightened Sovereign Control Paradigm: In Search of a New Legal Framework" (2018) 12(2) Brooklyn Journal of Corporate, Financial \& Commercial Law 241.

${ }^{128}$ E.g. see Villiers, supra. n122, calling for a class struggle that may overthrow capital from its throne at the top of the corporate hierarchy and socialise the corporate beast.

${ }^{129}$ Moore, M., "Private Ordering and Public Policy: The Paradoxical Foundations of Corporate Contractarianism" (2014) 34(4) Oxford Journal of Legal Studies 693.
} 
version of economic accumulation due to increased productive efficiency. ${ }^{130}$ So placing worker interests at the top of the bureaucratic corporation may indeed redistribute the benefits and costs of growth more fairly, but it will not necessarily or automatically offer a true alternative to the purpose of economic accumulation as a corporate legitimacy ground. So, both state and worker control solutions are still quite vague regarding what purpose corporate law ought to serve beyond a distributional one; they expressly or impliedly call for an equitable balance of power and wealth appropriation and little else.

On the other hand, Wilson argues that corporate law's social legitimacy can be restored via legal reform which can bring corporate goals in line with social ends. ${ }^{131}$ More specifically, as section 172 of the UK Companies Act 2006, the core provision on the corporate objective, obliges corporate directors to consider the externalities of economic accumulation, it might instigate a culture change within corporations and ultimately socialise them. Leaving aside the concerns regarding the meaning of section 172 expressed by others, ${ }^{132}$ the problem in Wilson's optimistic argument is that he does not explain how a more socially responsive corporate objective will in fact promote social goals which are radically different from or even irreconcilable with economic accumulation. Wilson's proposition relies on the assumption that a cultural shift has already taken place outside the corporation, so that all that is needed is the latter's adaptation. This is not only an unsubstantiated assumption, but it also contradicts the role of the corporation in the social loop of managerial capitalism discussed above. This optimistic view then stumbles on the same problems as the one relying on public discourse as a force of corporate socialisation. ${ }^{133}$ Thus, the cultural shift hoped for may eventually differ little from the social status quo and at best offer a restatement of corporate objective in its more nuanced guise of equitable economic growth.

\footnotetext{
130 See Arando, S., Gago, M., Jones, D. and Kato, T. "Efficiency in Employee-Owned Enterprises: An Econometric Case Study of Mondragon" (2015) 68(2) Industrial and Labor Relations Review 398. Taylor, P.L., "The Rhetorical Construction of Efficiency: Restructuring and Industrial Democracy in Mondragón, Spain" (1994) 9(3) Sociological Forum 459. For a study showing a small but positive impact of worker control on productivity see Jones, D., "The Productivity Effects of Worker Directors and Financial Participation by Employees in the Firm: the Case of British Retail Cooperatives" (1987-1988) 41(1) Industrial and Labor Relations Review 79. This is one of the important points where Weber and Marx differed with the former accepting that the action of what Marx termed as the proletariat and the bourgeois may be driven by similar ideologies, as systems of ideas are not necessarily a reflection of economic class relations; see Giddens, A., Capitalism and Modern Social Theory: an Analysis of the Writings of Marx, Durkheim and Max Weber, (Cambridge University Press, 1971), 185-204 and Birnbaum, N., "Conflicting Interpretations of the Rise of Capitalism: Marx and Weber" (1953) 4(2) British Journal of Sociology 125, 133-134.

${ }^{131}$ Wilson, G., "From Black Box to Glocalised Player - Corporate Personality in the Twenty-First Century and the Scope of Law's Regulatory Reach" (2011) 62(4) Northern Ireland Legal Quarterly 433.

132 Attenborough, D., "How Directors Should Act When Owing Duties to the Company's Shareholders: Why We Need to Stop Applying Greenhalgh" (2009) 20 (10) International Company and Commercial Law Review 339.

${ }^{133}$ See supra. n108-109 and text.
} 
Somewhat more pessimistically, Talbot relies on Marxist analysis to question the social legitimacy of corporate law altogether on the basis that it is a capitalist institution designed to serve shareholder interests while undermining the possibility of "creating an economy that delivers for people" though the development of "productive and innovative capacity". 134 While, given what is argued here, this approach is promising, Talbot's critique ultimately retains the economic accumulation frame as a legitimacy basis. If productive capacity ought to be the social goal of corporate law, it is difficult to see how this legitimacy basis differs from the economic accumulation objective, though probably once again in its more nuanced egalitarian form. Unfortunately, Talbot seems to fall once again back to the dichotomy between shareholder versus stakeholder economy or "bad" versus "good" profit, i.e. the distributional question, that she rightly critiques.

Wilson's and Talbot's claims are important in that they attempt to evaluate corporate law as a socially derived institution that requires justification as such and not necessarily on the basis of its distributional outcomes. However, they fail to offer a real alternative legitimacy frame that would not take economic accumulation as its starting point. So even radical scholars hesitate to divest the corporation of its conception as quintessentially an accumulation device serving growth. Thus, they indirectly deny the possibility of its legitimacy as an organisational species serving other purposes; they implicitly deny its history before capitalism where it was a public interest orientated institution. As a result, their proposed remedy is limited to a fair version of corporate accumulation which remains immersed in economic determinism, since it still deals with the issue of how (maximised) economic outcomes are to be distributed equitably.

Overall, not only has corporate law scholarship gradually become immersed in overt or covert economic determinism, it also serves as a carrier of the corporate logic. This type of theoretical closure is not only of academic interest, because it can have a wider social impact. Academic analysis furthers what Weber calls "theoretical rationalisation" to describe the process by which abstract models are developed in order to understand reality. ${ }^{135}$ The more analytically convincing and comprehensive these theoretical models become, the more capable they are also in contributing to the elevation of underlying value postulates as constellations of

\footnotetext{
134 Talbot, supra. n122, 534.

${ }^{135}$ Weber, M., "The 'Objectivity' of Knowledge in Social Science and Social Policy (1904)" in Bruun, H. and Whimster, S. (eds and trans.), Max Weber: Collected Methodological Writings (Routledge, 2012), 100.
} 
belief systems which can eventually determine and legitimise social practice and discourse. ${ }^{136}$ Academic theorisation can find its way into the social belief system and social organisation in various ways. For instance, and more obviously, it has the potential of influencing social action directly via normative propositions that may be picked up by policy on actual problems ${ }^{137}$ or by informing and helping in substantiating judicial reasoning. ${ }^{138}$ It may also have an indirect, but equally important, role by providing ex post or ex ante legitimacy to policy choices. Finally, theoretical understanding may also influence course curricula as dominant orthodoxies can create educational normative fads which can then sustain established practices; a phenomenon that is well documented especially, but not only, in the context of business schools. ${ }^{139}$

Thus, to the extent that scholarship can influence institutional development and organisational practice, it has become an advocate of the growth paradigm by expressly or impliedly offering a theoretical legitimacy gloss to it, even where this is done with some reluctance. Based on what has been argued above, the only plausible explanation for this is that corporate law per se is the problem, so that its legitimacy cannot be redefined without also revising the essential features of corporate law which are growth-oriented and have made it such an effective capitalist institution. Admittedly, this is a paralyzing dilemma for any corporate lawyer and shying away from it is probably an easier option. However, if scholarship is committed to a more socially constructive role instead of participating in the reproduction of the status quo, namely the "growth as progress" ideal, it will have to accept that corporate law's essential features are not sacrosanct.

This takes us to the main question of this article. Where does this realisation leave us with respect to the ability of corporate law reform to restore the legitimacy of business organisation?

\footnotetext{
136 See Kalberg, S., "Max Weber's Types of Rationality: Cornerstones for the Analysis of Rationalisation Processes in History" (1980) 85(5) American Journal of Sociology 1145, 1168; Van Leeuwen, T., "Legitimation in Discourse and Communication" (2007) 1(1) Discourse and Communication 91.

${ }^{137}$ E.g. see Copp, S., "Company Law Reform and Economics Analysis: Establishing Boundaries" (2001) 1 Journal of Corporate Law Studies 1; Deakin, S. and Hughes, A., Directors' Duties: Empirical Findings - Report to the Law Commission, ESRC Centre for Business Research, University of Cambridge, 1999; Keay, A., "Tackling the Issue of the Corporate Objective: An Analysis of the United Kingdom's Enlightened Shareholder Value Approach" (2007) 29 Sydney Law Review 577.

${ }^{138}$ Kendall, K. "The Use of Economic Analysis in Court Judgments: A Comparison between the United States, Australia and New Zealand" (2011) 28 UCLA Pacific Basin Law Journal 107.

${ }^{139}$ Mathews, P., "Academics as Agents of Change?" (2003) 9(1) Journal of the Australian and New Zealand Academy of Management 42. Colander, D., "The Making of an Economist Redux" (2005) 19(1) Journal of Economic Perspectives 175, 175; The Post-Crash Economics Society, Economics, Education and Unlearning: Economics Education at the University of Manchester, April 2014 available at http://www.postcrasheconomics.com/economics-education-and-unlearning/.
} 


\section{Can Corporate Law Reform Restore the Legitimacy of Business Organisation?}

Having established that the social role of corporate law is as an essential institutional part of the growth paradigm, one would need to go beyond the narrow limits set by corporate scholarship to restore the legitimacy of business organisation. That is, reform ought to include a re-evaluation of corporate law's essential features which have remained mostly unchallenged, if the inverted relationship between business organisation (law) and society is to be remedied. So the question to be answered here is if corporate law reform can indeed achieve this.

In this regard, three possible alternative courses of action are theoretically possible. First and less controversially, the corporation could be socialised by introducing mandatory participatory governance arrangements that could mitigate its bureaucratic suppression of radical reflection about organisational purposes; this could open up the legitimacy grounding of business organisation to allow the subjugation of growth to other social purposes. A second option in a similar direction would be to redesign corporate law in a way that precludes bureaucratisation altogether in order to deal with the social loop problem. Finally, a more drastic solution would be to turn the clock back by revoking general incorporation rights which could be placed again under some form of social control. However, very quickly it will be seen that all these alternatives are destined to fail for a variety of reasons.

To begin with, we have already seen that proposals relying on opening up the meaning of the corporate objective in a state-sponsored stakeholderism via legal intervention cannot provide a true alternative. As mentioned above, such reforms would merely deal with the secondary distributional question leaving the primary governance issue raised here totally untouched. $^{140}$ At best, a worker-controlled or more pluralistic governance model - e.g. a representational board structure - for the (still) managerial corporation could possibly encourage or facilitate some deliberative process which could influence corporate strategy. However, it is difficult to imagine how that could lead to a deep reflective exercise about the primary corporate goal that could even contemplate the rejection of economic accumulation and its replacement by something else. Pluralistic board representation has been tried in practice widely and for long enough, with German law usually offering the leading example. The evidence shows that governance related information flows in this model have the effect of either enhancing managerial autonomy from outside (financial) interests or simply tempering

${ }^{140}$ See supra. $\mathrm{n} 127$ et seq and text. 
the distributional outcomes of corporate governance. ${ }^{141}$ This is not at all surprising, since as discussed above, ${ }^{142}$ the normative theory behind this model is far from capable of leading to a radically different vision of the business organisation; it simply deals with the distributional problem and retains the growth objective. It is no wonder the UK government recently flirted with the idea of worker board representation, not as a way of breaching corporate accumulation, but rather as a device for the promotion of industrial expansion. ${ }^{143}$ It is therefore quite irritating that, in spite of its long history of failure to introduce a social ethos even where it is practiced, representation is still advocated for as a way of mitigating the social hazards of business growth. At best it is a distributional measure at the cost of even greater growth.

On the other hand, even if representational pluralism could hypothetically lead to a topdown process of redefining the corporate objective once, the problem of conformism inherent in bureaucratic organisation would not be mitigated. Once altered, the new objective and the social groups supporting it would crystallise and get entrenched, so as to reflect the instituted social imaginary which would once again be reproduced through another social loop as currently is the case with the capitalist imaginary. Certainly, one could hope for the Weberian solution to bureaucratic conformity, which relies on the charismatic entrepreneurial leadership or, in our case, the charisma of the representational board members to alter organisational objectives. As we have already seen, this is unsatisfactory due to its contingent nature and to wider structural factors. This solution would presuppose that such board members are either asocial, so as to be unaffected by the instituted social imaginary and its respective social loop processes, or that they somehow impose their presence on boards from some other socialhistorical space determined by another social imaginary. This is once again an extra-social type of "solution" which could be compared with hoping for some extra-terrestrial salvation force against societal problems. There is no obvious reason for a bureaucratic organisation to ever invite such incompatible leadership. The dead-end of the representational model as a solution to the hazards associated with corporate law should be clear by now to the reader.

Certainly, the second possible option for corporate law reform would be to "debureaucratise" the (still private) corporation, but this is easier said than done. It would involve the abolition of those aspects of the corporate anatomy, which enable its evolution into a bureaucratic organisation. Where would one who wishes to retain the identity of a "corporate lawyer" begin: from the abolition of the entity shielding effect of corporate personality, from

\footnotetext{
${ }^{141}$ See Dignam, A. and Galanis, M., The Globalization of Corporate Governance (Ashgate, 2009), chapter 7.

142 See part 4 above.

${ }^{143}$ Department for Business, Energy and Industrial Strategy, Corporate Governance Reform, 2017.
} 
the prohibition of holding companies in order to control mergers and acquisitions, or from the obliteration of the share as an independent asset? If we did this, what would be left of the corporation and its law other than an empty shell? This is indeed the dead end faced by corporate law scholarship in its inability to offer a radicalised corporate form; it is impossible.

Alternatively, one could retain the corporate law anatomy intact and simply implant an accumulation break within corporate law broadly defined. This could take the form of an external rule, say, punitive taxation over a certain socially defined threshold or an active deconcentration policy using competition law. Of course, such measures would be and are pointless within our current social-historical condition, but a hypothetical future society could perhaps develop the political structures necessary for their effective implementation. But which jurisdiction will be the first mover towards such a regulatory direction by accepting the significant social costs in the short and medium term that will inevitably ensue ${ }^{144}$ Even so, for such rules to emerge the prior dismantling of corporate bureaucratic influence is a precondition otherwise regulatory policy capture will water down and cancel such measures. Indeed, the conformist nature of regulatory reform following the global financial crisis a decade ago suggests that even generalised social catastrophe may not be enough to trigger radical corporate law changes. ${ }^{145}$ Corporate law seems to be significantly captured by vested corporate interests that, if anything, one would reasonably expect its reform to further enhance the social loop's subversive effect rather than contain it. That corporations are now being offered additional protections of a truly public law nature through constitutional and human rights law at both national and international levels is a clear illustration of the problem. ${ }^{146}$ Thus, one is left with a chicken and egg problem or, worse, another dead-end. Thus, one is left with a chicken and egg problem or, worse, another dead-end.

Finally, if setting the social costs or the implementation problem aside was possible, one could simply try to bring the corporation under direct public control once again in order to decorporatise business organisation law. This would require rolling back the general

\footnotetext{
${ }^{144}$ For instance, a "green" tax on industrial energy consumption in the UK was very much a failure; see Desai, P. and Riddlestone, S., Bioregional Solutions for Living on One Planet (Green Books, 2002), 40-42.

${ }_{145}$ Avgouleas, E., Buckley, R. and Arner, A. (eds), Reconceptualising Global Finance and Its Regulation (Cambridge University Press, 2016), 3-6; Hardie, I. and Macartney, H., "EU Ring-Fencing and the Defence of Too-Big-To-Fail Banks" (2016) 39(3) West European Politics 503; Bell, S. and Hindmoor, A., "Are the Major Global Banks Now Safer? Structural Continuities and Change in Banking and Finance Since the 2008 Crisis (2018) 25(1) Review of International Political Economy 1.

${ }^{146}$ Grear, A., "Human Rights - Human Bodies? Some Reflections on Corporate Human Rights Distortion, the Legal Subject, Embodiment and Human Rights Theory" (2006) 17 Law and Critique 171; Greenwood, D., "Neofeudalism: The Surprising Foundations of Corporate Constitutional Rights" (2017) University of Illinois Law Review 163.
} 
incorporation rights granted by corporate law statutes to private business and allow the corporate form only where there is a clear public interest being served. However, this option also suffers from the same fallacies as the proposition for increasing state control rights over the bureaucratic corporation and the "growth-break" option critiqued above; the state cannot be the agent of radical change unless bottom-up social pressure demands it. We have seen how corporate influence on policy-making can subvert such radical reform to neutralise it or render it conformist. In this context, why would the state abandon its growth-oriented policy when it has been proven unable to do so while in full control of privatised corporate law? The most extreme example is perhaps the unchanged objectives and practices of the directly and indirectly nationalised banking sector following the last financial crisis or even the growth orientation of the Chinese economy's central plan. Then, there is also the first-mover constraint created by capital's ability to relocate. But even if these problems could be ignored, a number of other questions would also need to be unanswered. What will safeguard the alignment of the corporate purpose with the public interest? Who will monitor this and by what process? In any case, why would the organisational form of the corporation rather than a typical state bureaucracy be preferable? These are indeed the problems faced by society in the formative era of capitalism and history has demonstrated the answers again depend on the prevalent social ideal. Without radical social change the answers are bound to be similar to those given in the $19^{\text {th }}$ century; incorporation rights are unlikely to be revoked without prior social change which is, however, undermined by corporate law.

What seems clear though is that, due to the social loop problem and the associated practical difficulties presented here, it is virtually impossible to imagine how corporate law reform could drive social transformation this time; the relationship of corporate law with society seems to be stuck in the inverted mode. The analysis above and our experience so far undeniably demonstrate that implementation problems and regulatory capture at best preclude radical reform or, worse, enhance conformism. It would therefore be preferable for corporate law reform to be completely aborted for being wasteful or harmful.

If radical corporate law reform is impossible, how can then the social legitimacy of business organisation (law) ever be restored? The final section will show that the answer lies within radical organisational practice already occurring outside the narrow limits of the corporatised business organisation. This has also important implications for the nature and focus of reform policy. 


\section{In Lieu of a Conclusion: The Need for Radical Reform Beyond Corporate Law}

Thus far, the discussion has followed the evolution of business organisation law to show that within capitalism, it is effectively corporatised as a structural reflection of the "growth as progress" ideal. It has also been argued that this organisational development constitutes the legal platform for wider social processes rendering this ideal a structural concern which is being constantly reproduced. The nature of things is such that corporate law reform cannot offer any promising or realistic solution and, in fact, experience shows it may even exacerbate the problem where it is attempted.

However, this negative finding by no means supports a claim that the legitimacy of business organisation can never be restored; it simply cannot be restored with corporate law reform. Social change can never be completely foreclosed and is always underway, ${ }^{147}$ even if corporate law will not be instrumental in this as it was a few centuries ago when capitalism was emerging. Indeed, society has never stopped producing in its margin structures for business that radically differ from the corporation in terms of purpose and governance methods. ${ }^{148}$

For instance, efforts such as the cooperative movement that begun in $19^{\text {th }}$ century Rochdale in response to corporate capitalism, successful commons governance structures for commonpool sources or, more recently, localised community initiatives for energy supply prove that modern society still contains sufficient nuclei of social entrepreneurship carrying social imaginaries from which may spring new organisational forms for business. ${ }^{149}$ Such governance structures are based on organisational norms which disrupt bureaucratic conformism primarily by adopting flat, non-hierarchical decision-making requiring active participation by membership. Thus, they rely on deliberation about corporate purpose without its prior anchoring in a growth-oriented framing. ${ }^{150}$ In an organisation of this type it is essential that individual participants must accept opinion divergence and the importance of deliberation as a social relation rather than as an organisational practice moulded so as to fit a predetermined

\footnotetext{
${ }^{147}$ Castoriadis, C., supra. $\mathrm{n} 22$.

${ }^{148}$ For an overview of this parallel universe to US corporate capitalism see Schneiberg, M., "Toward an Organizationally Diverse American Capitalism: Cooperative, Mutual, and Local, State-Owned Enterprise" (2011) 34 Seattle University Law Review 1409.

${ }^{149}$ Ostrom, E., "Beyond Markets and States: Polycentric Governance of Complex Economic Systems", (2010) 100(3) American Economic Review 1; Cumbers, A., "Constructing a Global Commons in, Against and Beyond the State" (2015) 19(1) Space and Polity 62 and Reclaiming Public Ownership: Making Space for Economic Democracy (Zed Books, 2012), esp. ch.9; Rothschild, J. and Russell, R., "Alternatives To Bureaucracy: Democratic Participation In The Economy" (1986) 12 Annual Review of Sociology 307.

${ }^{150}$ Rothschild-Whitt, J., "The Collectivist Organization: an Alternative to Rational-Bureaucratic Models" (1979) 44(4) American Sociological Review 509.
} 
(economic) outcome. Following such governance processes, growth may indeed be selected as a goal, but it may also be rejected or subjected to other higher principles determined by wider, extra-business social practices and debates. This is a business organisation which does not strive to be the sole or primary forum of social debating and structuring. It requires and shapes through regular participation in governance ${ }^{151}$ a different anthropological type to the homo oeconomicus who is socialised under the influence of the "growth as process" ideal. Thus, there is already ample evidence of the use of business organisation for the purpose of implementing wider social objectives. ${ }^{152}$ Even so, these democratically governed alternatives to the bureaucratic corporation have proven to be economically viable. ${ }^{153}$ This shows that radically diverse social imaginaries can indeed define the business organisation which can once again perform a social entrepreneurship role.

Certainly, as mentioned above, initiatives and structures of this type are still operating in the social margin. However, a closer look may reveal to most of us that this margin may only be a few steps away - it certainly is for this author. Moreover, social crises of various types and at various strata will also contribute to the proliferation of such radical business practice. For instance, environmental concerns have already given rise to a social imaginary which contradicts the value system supporting wealth accumulation. ${ }^{154}$ Similarly, economic hardship leads to ad hoc incidents of radical reorganisation of failed corporations along the lines of the participatory structures outlined above. ${ }^{155}$

Policy and law reform can and will only follow individual and grassroots action of this type as it did in the past. However, ultimately the synergy of both is necessary for wider social change to proceed. Undoubtedly, radical business organisations, such as those mentioned above, have to struggle against the pressurised environment institutional isomorphism creates for them within the current mode of capitalism. ${ }^{156}$ The role of policy in alleviating some of

\footnotetext{
${ }^{151}$ Pateman, C., Participation and Democratic Theory (Cambridge University Press, 1970).

152 Psarikidou, K. and Szerszynski, B., "The Moral Economy of Civic Food Networks in Manchester" (2012) 19(3) International Journal of Sociology of Agriculture and Food 309.

${ }^{153}$ E.g. see Blasi, J. et al., The Citizen's Share: Putting Ownership Back into Democracy (Yale University Press, 2013); Birchall, J., "The Potential of Co-operatives During the Current Recession: Theorizing Comparative Advantage" (2013) 2(1) Journal of Entrepreneurial \& Organizational Diversity 1; Gupta, C., "The Co-operative Model as a 'Living Experiment in Democracy"' (2014) 2 Journal of Co-operative Organization and Management 98.

${ }^{154}$ Levy, D. and Spicer, A., "Contested Imaginaries and the Cultural Political Economy of Climate Change" (2013) 20(5) Organization 659.

${ }^{155}$ Vieta, M. and Ruggeri, A., "Worker-Recovered Enterprises as Workers' Co-Operatives: The Conjunctures, Challenges, and Innovations of Self-Management in Argentina and Latin America" in Reed, D. and McMurtry, J. (eds.), Co-operatives in a Global Economy: The Challenges of Co-operation Across Borders (Cambridge Scholars Publishing, 2009), 178.

${ }^{156}$ DiMaggio, P. and Powell, W. "The Iron Cage Revisited" Institutional Isomorphism and Collective Rationality in Organizational Fields" (1983) 48 American Sociological Review 147; Levi, Y. and Davis, P., "Cooperatives as
} 
those pressures cannot be overestimated. Facilitating organisational innovation and change in the margin, outside of the growth-reproducing social loop in the core of which lies corporate law and in parallel to it, will be necessary. Social crises are bound to increase the demand for such policies.

Indeed, evidence of such policy reform is already emerging, as the introduction of new forms like the Benefit Corporation (B-Corp) and the Low-Profit Limited Liability Company (L3C) in the US or the Community Interest Company (CIC) in the UK denotes there is a demand for organisation forms that can accommodate non-capitalist purposes. Evaluating such forms is beyond the scope of this discussion, but the findings above suggest that to the extent they replicate corporate law, their impact will be limited. The first appraisals of the B-Corp and the L3C seem to confirm this prediction, whereas the degeneration of the CIC towards corporatisation is already under way. ${ }^{157}$ Instead, paradigm change will require and go hand-inhand with organisational structures which have divested or circumscribed the growth-oriented features of corporatised business organisation law. This is fertile ground for scholarship in this field to articulate the legal traits of such structures which may evolve independently of corporate law. Finally, additional efforts will be necessary, such as fiscal incentives, financial facilitation, accommodative accounting, to name but a few possible areas where regulatory action may contribute to creating an environment for the proliferation and demarginalisation of radical organisational alternatives.

In short, focusing on the margin with enabling regulatory action will be a more effective approach than attempting in vain to reform the corporate law centre. Creating social space for radical organisational praxis is the most realistic way for the privatised bureaucratic corporation to be relegated to some dark corner of our reimagined future, as other radically different forms emerge to replace it. The quicker and more effective policy gets in this respect, the sooner the social legitimacy of business organisation will be restored.

$* * * * *$

the 'Enfants Terribles' of Economics: Some Implications for the Social Economy" (2008)37 'Journal of SocioEconomics 2178, 2183-2185; Mukherjee Reed, A. and Reed, D., "Globalization and Co-operative Development: The Challenges of the Alternative Globalization Movement" in Reed and McMurtry, ibid., 242.

${ }^{157}$ Cummings, B., "Benefit Corporations: How to Enforce a Mandate to Promote the Public Interest" (2012) 112 Columbia Law Review 578; Collins, J. and Kahn, W., "The Hijacking of a New Corporate Form? Benefit Corporations and Corporate Personhood" (2016) 45(3) Economy and Society 325; Callison, J. and Vestal, A., "The L3C Illusion: Why Low-Profit Limited Liability Companies Will Not Stimulate Socially Optimal Private Foundation Investment in Entrepreneurial Ventures" (2010) 35 Vermont Law Review 273. With respect to the CIC's corporatisation, the Community Interest Company (Amendment) Regulations 2014 removed the cap originally imposed on profit distributions to shareholders. 